JOURNAL of

TOXICOLOGY and

ENVIRONMENTAL

HEALTH
Journal of Toxicology and Environmental Health, Part A

\title{
Quantifying structural modifications of gills of two fish species Astyanax altiparanae (Lambari) and Prochilodus lineatus (Curimbatá) after exposure to biodegradable detergents in urban lake water
}

Bruno Fiorelini Pereira, Anderson Luis Alves, José Augusto Senhorini, Priscilla Hakime Scalize, Fellipe Augusto Tocchini De Figueiredo, Dimítrius Leonardo Pitol \& Flávio Henrique Caetano

To cite this article: Bruno Fiorelini Pereira, Anderson Luis Alves, José Augusto Senhorini, Priscilla Hakime Scalize, Fellipe Augusto Tocchini De Figueiredo, Dimítrius Leonardo Pitol \& Flávio Henrique Caetano (2017) Quantifying structural modifications of gills of two fish species Astyanax altiparanae (Lambari) and Prochilodus lineatus (Curimbatá) after exposure to biodegradable detergents in urban lake water, Journal of Toxicology and Environmental Health, Part A, 80:6, 338-348, DOI: $10.1080 / 15287394.2017 .1323254$

To link to this article: https://doi.org/10.1080/15287394.2017.1323254

Џ Article views: 82 


\title{
Quantifying structural modifications of gills of two fish species Astyanax altiparanae (Lambari) and Prochilodus lineatus (Curimbatá) after exposure to biodegradable detergents in urban lake water
}

\author{
Bruno Fiorelini Pereira ${ }^{a}$, Anderson Luis Alves ${ }^{b}$, José Augusto Senhorinic ${ }^{c}$ Priscilla Hakime Scalize ${ }^{d}$, \\ Fellipe Augusto Tocchini De Figueiredo $\mathbb{( 1 )}^{\mathrm{e}}$, Dimítrius Leonardo Pitol ${ }^{\mathrm{d}}$, and Flávio Henrique Caetanof
}

aSchool of Biology and Human Health, The Federal University of Western Bahia, Barreiras, Brazil; bGenetics Department, EMBRAPA, Palmas, Tocantins, Brazil; 'Reproduction Department, ICMBio/CEPTA, Pirassununga, Sao Paulo, Brazil; dMorphology Physiology and Basic Pathology Department, School of Dentistry of Ribeirao Preto, FORP/USP, University of Sao Paulo, Ribeirao Preto, Sao Paulo, Brazil; eBioengineering Department, School of Medicine of Ribeirao Preto, University of Sao Paulo, Ribeirao Preto, Sao Paulo, Brazil; fBiology Department, Rio Claro Campus, São Paulo State University, São Paulo, Brazil

\begin{abstract}
Anthropic actions in rivers and urban lakes are a cause for concern to our ecosystem. The effects on fauna and flora of substances discharged into waterways have become a focus for investigations globally. Biodegradable detergents are widely used in residences and small industries, but little is known regarding the consequences on fish fauna. The objective of the present study was to identify modifications in gill structure in two fish species, Astyanax altiparanae and Prochilodus lineatus, after treatment with water obtained from an urban lake and an exposure to $1 \mathrm{ppm}$ diluted biodegradable detergents (linear alkylbenzene sulfonate). Data demonstrated exposure to urban lake produced various alterations in gill functions such as lamellar fusions, aneurysms, mucous, and chlorine cell proliferation, which may be attributed to the presence of detergents in the water but may also be a consequence of synergetic actions of detergents with other pollutants. Results showed that the levels of $\mathrm{NO}^{-}{ }_{2}, \mathrm{Na}, \mathrm{F}^{-}, \mathrm{Cl}^{-}$, and Fe were significantly higher in urban lake water but in the presence of detergents Ni was also detected. Evidence indicates that biodegradable detergents produce damage to gill functions, which subsequently alters the fish physiology and reduces the ability to cope with stress and survival.
\end{abstract}

\section{ARTICLE HISTORY}

Received 24 February 2017

Accepted 22 April 2017

\section{Introduction}

The rapid increase in domestic, agricultural, and industrial activities in developing countries contributes to water pollution and reflects the presence of chemical compounds derived from human activities (Silva et al., 2003; Strbac et al., 2015; $\mathrm{Vaz}$ et al., 2016). Aquatic ecosystems are fragile and fish species are under different types of threats, including loss of fish habitat due to poor water management practices, release of effluents into the natural water bodies, and several anthropogenic activities (Aich et al., 2015; De Campos et al., 2016; Hawkins et al., 2015; Kaur \& Dua, 2015; Strbac et al., 2015; Wolff et al., 2016).

In fish, organs such as gills are in direct contact with water and consequently morphological alterations reflect reversible or irreversible disturbances in fish physiology (Reis et al., 2009). Moreover, gills are vital structures to fish health because in addition to being the main location of gas exchange, these organs are also involved in osmoregulation, acidbase balance, and excretion of nitrogenated compounds (Leonardo et al., 2008). In addition to mucous cells, mitochondria-rich cells also respond to physical and chemical alterations in water, which stimulate either hypertrophy or hyperplasia (Silva et al., 2003). These cells are larger than mucous cells and carry a large number of mitochondria that fuel maintenance of homeostasis in fresh water teleostei that compensate ionic loss and water gain (by osmosis) by absorbing active forms of $\mathrm{Na}^{+}, \mathrm{Cl}^{-}$, and $\mathrm{Ca}^{+}$(Camargo et al., 2009).

Teleostei have five pairs of gill arches consisting of numerous gill filaments and secondary lamellae

CONTACT Dr. Fellipe Augusto Tocchini de Figueiredo fellipe.figueiredo@usp.br; eufeeu@gmail.com 9 School of Medicine of Ribeirão Preto, Faculdade de Medicina de Ribeirão Preto, University of Sao Paulo, Avenida do Café, S/N, CEP: 14040-904, Ribeirão Preto, Sao Paulo, Brazil, Tele: +55 1633154094 Color versions of one or more of the figures in the article can be found online at www.tandfonline.com/UTEH. 
(Leonardo et al., 2008). The lamellae are situated at a right angle to the filamental axle and represent functional respiratory surface through which oxygen is absorbed and diffused into tissues and blood (Jobling, 1994; Leonardo et al., 2008). These lamellae are covered by epithelial cells and formed by pillar, mucous, and mitochondria-rich cells (Leonardo et al., 2008; Takashima \& Hibiya, 1995). Many pathological and chemical agents are known to produce histological alterations in gills including edema and epithelial hyperplasia of secondary lamella, epithelial cell infiltration, lamellar fusion, and in some cases death of mucous cells induced by hypersecretion (Hawkins et al., 2015; Leonardo et al., 2008; Takashima \& Hibiya, 1995). Morphological gill modifications are commonly recognized as a response to environmental changes (Monteiro et al., 2008) and are linked to physiological dysfunctions and endocrine system depending upon ionic concentration of chemicals in the water (Fernandes \& Perna-Martins, 2001). In addition to mucous cells, mitochondriarich cells also respond to physical and chemical alterations in water, which stimulate either hypertrophy or hyperplasia (Silva et al., 2003). These cells are larger than mucous cells and carry a large number of mitochondria that fuel maintenance of homeostasis in fresh water teleostei that compensate ionic loss and water gain (by osmosis) by absorbing active forms of $\mathrm{Na}^{+}, \mathrm{Cl}^{-}$, and $\mathrm{Ca}^{+}$(Camargo et al., 2009).

Fresh water environments may serve as a source of environmental pollution and contaminants may be transported to fish and subsequently humans (Adeogun et al., 2016; Amundsen et al., 2011; Wolff et al., 2016). Industrial mining activities, metal processing, and industrial and domestic waste hat are released in water bodyes can increase the concentration of various heavy metals in natural environments (Abel, 1996; Domingos, 2006) that than can be bioaccumulated by several organisms and incorporated into the trophic chain, reaching a large part of the aquatic ecosystem, including fish that serve as biomarkers for these types of contaminants (Abel \& Skidmore, 1975; Baraj et al., 2011).

Among these contaminants are surfactants used in industrial processes and residences that have one of the highest rates of industrial production among all the organic products (Ogeleka et al., 2011). The ability to form pseudo micellar structures that absorb other organic pollutants results in complexes that are subsequently released into the environment and may thus be responsible for adverse biological effects (Ogeleka et al., 2011). Linear alkylbenzene sulfonate (LAS) is a common surfactant used in commercial detergents that induced morphological gill alterations in several fish species (Ogeleka et al., 2011).

Due to the current concern with impacts of contaminants in urban rivers and lakes, the present study aimed to identify changes in gill morphology and mucous and mitochondria-rich cells as well as lysosome numbers in two largely distributed (throughout South America) and commercially important fish species, Prochilodus lineatus and Astyanax altiparane after exposure to urban pollutants present in urban lake water and with a focus on detergent contamination.

\section{Materials and methods}

Sixty specimens of each species, age-standardized (4 months) to avoid differences in results due to developmental stage, were obtained from the Fish Reproduction Laboratory of ICMBio/CEPTA, Pirassununga, Sao Paulo, Brazil. The animals were kept in $500 \mathrm{~L}$ fish tanks until 3 months old for $P$. lineatus and 4 months old for A. altiparanae. These individuals were divided into three groups: control, kept in pure water from the artesian well at UNESP, Campus de Rio Claro, Sao Paulo, Brazil; detergent, kept in a 1 ppm (demonstrated by Pereira et al., 2012, as level that can be found in Brazilian lakes) commercial biodegradable detergents; and lake, kept in water obtained from a lake that receives sewage from residences, small industries, and gas stations. Two sampling periods were determined: the first after 1 month and the second after 5 months. These periods were selected to simulate a long-period exposure to these pollutants, as the acute experiments were previously reported by Pereira et al. (2012). All experiments were performed in duplicate (each one with 30 specimens of each specie, and 5 fish sacrificed from each sampling period.)

\section{Sampling for morphologic analysis}

Before sampling, fish were anesthetized with benzocaine $(0.1 \mathrm{~g}$ benzocaine in $1 \mathrm{ml}$ ethyl alcohol for each $100 \mathrm{ml}$ deionized water). After anesthesia, six 
individuals were euthanized per group in each sampling period. The gill arches were removed and fixed in aqueous Bouin solution for $48 \mathrm{hr}$ at $4^{\circ} \mathrm{C}$. All samples were buffered in sodium phosphate solution $\mathrm{pH}$ 7.4, dehydrated in alcohol, embedded in Leica HistoResin, and sectioned in a Leica RM224micotome.

\section{Analyses of gill morphology}

Five $6-\mu \mathrm{m}$ sections were obtained from each individual under study and mounted on glass slides that were submitted to hematoxylin and eosin (HF) according to Becak and Paulete (1976). Six gill filaments in each section were analyzed to identify morphological alterations in secondary lamellae. Morphologic changes were counted and an arithmetic mean obtained for each treatment in both sampling periods. The results were statistically analyzed and are shown in Figures 1 and 2 with \% from each group in each sampling period to demonstrate which type of morphological alteration was the most frequent.

\section{Mucous cell count}

Six $\mu \mathrm{m}$ sections per individual were mounted on glass slides and submitted to PAS technique according to Becak and Paulete (1976). Mucous cells between secondary lamella of six gill filaments were counted on five sections for each individual. Arithmetic means were calculated for individual of each group in both sampling periods and statistically compared.

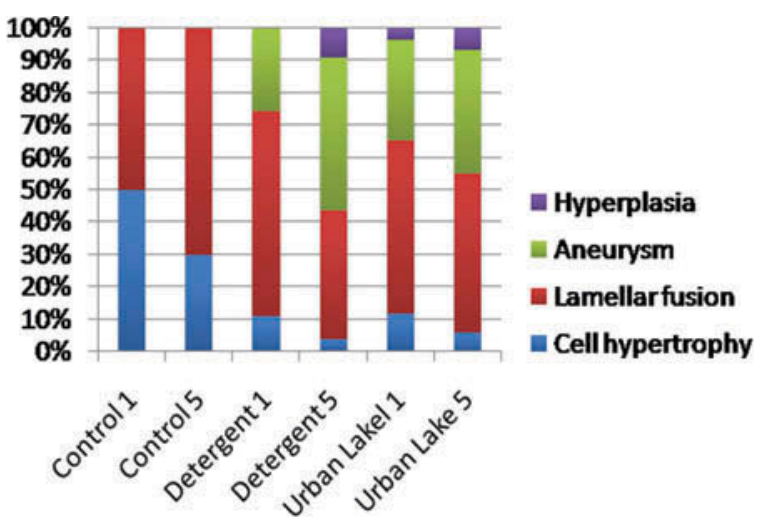

Figure 1. Percentage of each morphological modifications present in each group for Astyanax altiparanae. The number in front of the group represents the month where the data were collected.

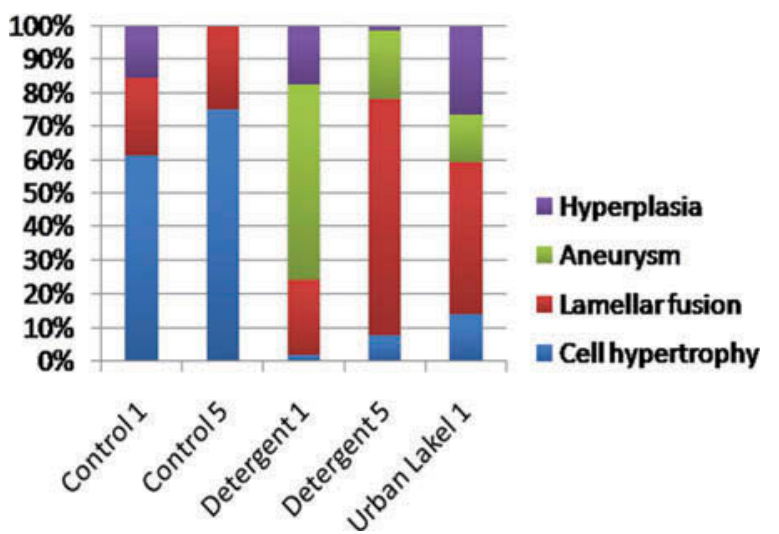

Figure 2. Percentage of each morphological modifications detected in each group for Prochilodus lineatus. The number in front of the group represents the month where the data were collected.

\section{Mitochondria-rich cell count}

Mitochondria-rich cells were identified according to Pereira and Caetano (2009). Seven $\mu \mathrm{m}$ sections were obtained from each specimen, mounted on glass slides, and submitted to Von Kossa stain. Six filaments per section in five sections per individual were analyzed, and mitochondria-rich cells counted at every interval of 10 secondary lamellae in each filament. Arithmetic means were calculated and statistically analyzed for each group.

\section{Lysosome identification}

Five 7 - $\mu \mathrm{m}$ sections were obtained from each individual mounted on glass slides according to Gomori (1950) technique. The measurements were made using the program Image (NIH, USA), with the plugin Counter Cell, considering each brown point as a positive result for the technique.

\section{Chemical analysis of water}

Water samples from all treatments were sent to the Water Analysis Laboratory of the Department of Applied Geology at the Institute of Geosciences and Exact Sciences UNESP, Campus de Rio Claro. Analyses were carried out following norms of the Standard Methods for the Examination of Water and Wastewater, for the following parameters. Metal concentration was determined by ICP-AES (equipment precision guaranteed at 
concentrations between 1 and $10 \mathrm{ppb}$ ) for the following elements: $\mathrm{Mg}, \mathrm{Ca}, \mathrm{Sr}, \mathrm{Ba}, \mathrm{Cr}(\mathrm{t}), \mathrm{Mn}, \mathrm{Fe}$, $\mathrm{Co}, \mathrm{Ni}, \mathrm{Cu}, \mathrm{Zn}, \mathrm{Cd}, \mathrm{Si}, \mathrm{P}(\mathrm{t})$, and $\mathrm{Pb}$.

Concentration of anions: $\mathrm{F}^{-}, \mathrm{Cl}^{-}, \mathrm{NO}_{2}, \mathrm{NO}_{3}, \mathrm{PO}_{4}$, $\mathrm{SO}_{4}, \mathrm{ClO}_{2}{ }^{-}$, acetate and oxalate plus cations $\mathrm{Li}, \mathrm{Na}$, $\mathrm{NH}_{4}$ and $\mathrm{K}$ was determined by ionic chromatography. Conductivity, $\mathrm{pH}$, total alkalinity, and concentration of carbonates were also analyzed by potentiometric titration. Samples from all groups were taken for this analysis, cooled immediately at $4^{\circ} \mathrm{C}$, and taken to the lab (Pereira et al., 2012).

Although constant detergent concentrations were used, it was still necessary to assess true LAS concentration, as it is the main component of domestic detergents. Chromatographic analyzes were carried out in an Agilent Tecnologies 1200 series HPLC, with fluorescence detector. This test was performed by Global Análise \& Consultoria, São Carlos, Sao Paulo, Brazil. The same test was carried out with water from the urban lake to identify possible LAS concentration. Samples from all the groups were taken for HPLC analysis diluted in $300 \mathrm{ml}$ and then frozen at $-20^{\circ} \mathrm{C}$ before analysis (Pereira et al., 2012). The HPLC analysis determined pollutant concentrations with precision in solutions with concentrations higher than $0.002 \%$.

\section{Statistical analyses}

All obtained data were analyzed with BioEstat 5.0. Shapiro-Wilk normality test was applied to identify variations among results and ANOVA/Tukey or Kruskal-Wallis/Dunn variance tests were used on parametric and nonparametric data, respectively. The criterion for significance was set at $p<0.05$.

\section{Results}

\section{Survival}

In the experiment with $A$. altiparanae, the mortality was zero in all three treatments throughout the experiment. With $P$. lineatus control and detergent groups, there was no mortality throughout the experiment, but individuals from urban lake groups only survived up to 35 days, and therefore only the first group of samples was taken.

\section{Morphological alterations}

Four types of morphological changes were found: lamellar fusion, secondary lamella pavement cell hypertrophy, aneurysm, and hyperplasia of gill filament epithelium (Figure 3). In the experiments with $A$. altiparanae, groups treated with detergent and lake water showed a significant high incidence of lamellar fusion and aneurysm in both sampling periods (Figure 1). Significant differences were found between contaminated and control groups in structural changes (Table 1),

In the case of $P$. lineatus, similar patterns of morphological changes were noted (Figure 4 and Table 2). Individuals exposed to detergent, similar to A. altiparanae, showed a greater incidence of lamellar fusions and aneurysms (Figure 2). On the other hand, individuals exposed to urban lake water developed lamellar fusions an epithelial cell hyperplasia in gill filaments more frequently and, in some cases, hyperplasia covered all the space between secondary lamellae.

\section{Mucous cell analysis}

In $A$. altiparanae, both groups exposed to pollutants exhibited significant large amounts of mucous cells compared to control. These cells were found in secondary lamella and far from it (Figure 5). In addition to an increase in mucous cell number, lamellar fusion was sometimes initiated by mucous cell fusion (Figure 5). Lamellar fusion between two adjacent filaments displayed greater numbers of mucous cells. The same results found for $P$. lineatus A. (Figure 5, Table 2).

\section{Mitochondria-rich cell analysis}

Mitochondria-rich cells of $A$. altiparanae were strongly reactive to Von Kossa stain, with several cytoplasmic granulations and in some cases, intense perinuclear and nuclear reaction (Figure 6). These cells responded antagonistically in polluted groups compared to control. Detergent decreased the number of mitochondria-rich cells, while urban lake waters increased the number of cells (Table 1). Mitochondria-rich cells in both groups exposed to pollutants were significantly reduced compared to control in $P$. lineatus. Not 

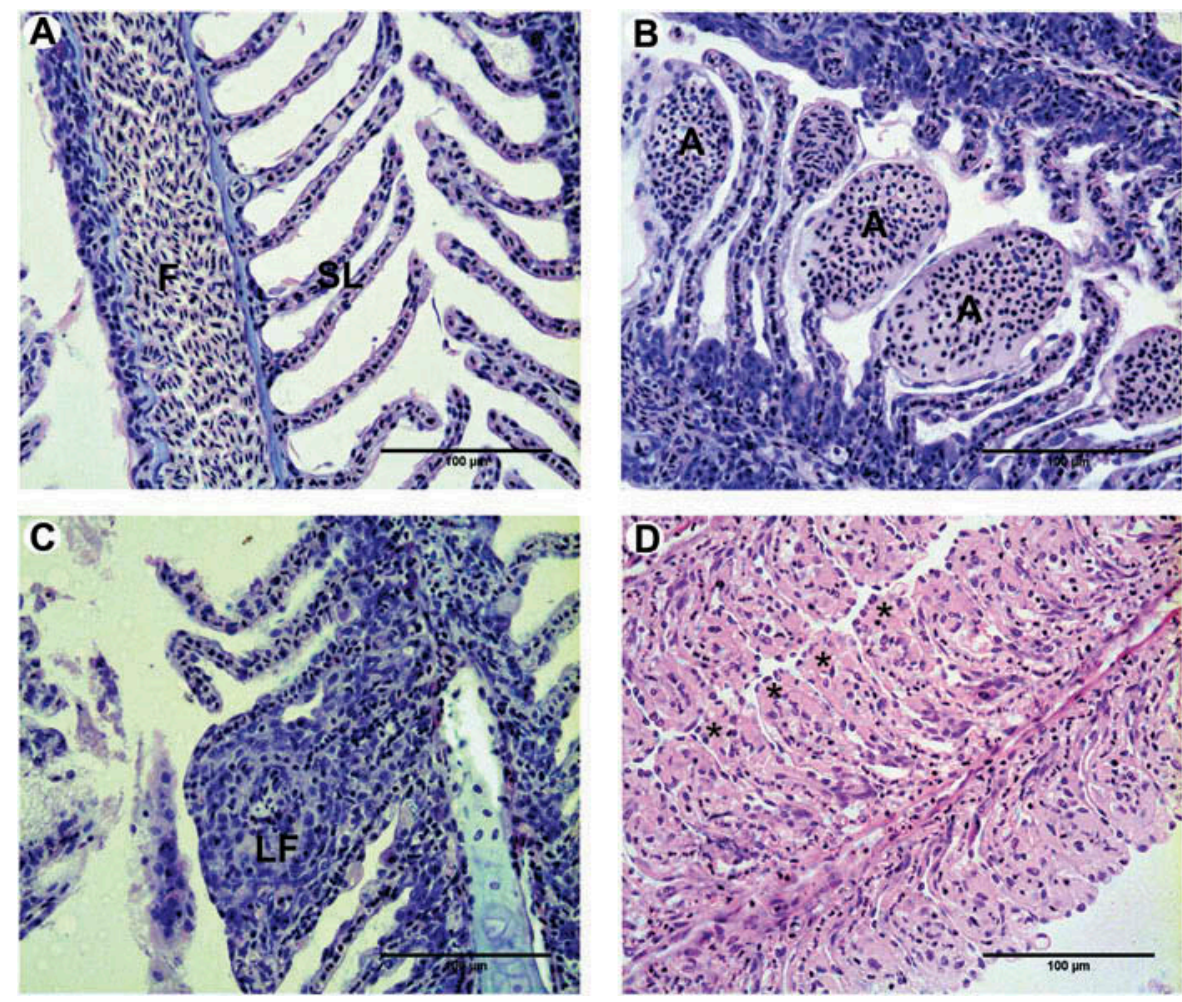

Figure 3. A - normal morphology of the gill in Astyanax altiparanae, showing the gill filament (F) and the secondary lamellae (SL); $B$ - gill of $A$. altiparanae, showing aneurysms (A) in secondary lamellae; $C$ - gill of $A$. altiparanae, showing lamellar fusion (LF); D - gill of $A$. altiparanae, showing cell hypertrophy, note the cytoplasmic dilatation $\left(^{*}\right)$.

Technique: $\mathrm{H}-\mathrm{E}$.

Table 1. Average of mucous cells, chloride cells, and total morphological alterations found in the gills of Astyanax altiparanae. Note the increase in the number of mucous cells and morphological changes in the groups exposed to detergent and the urban lake water, compared to the control and the reduction in chloride cells in the exposed detergent and increase in this parameter above the lake water during the entire experiment.

\begin{tabular}{|c|c|c|c|c|c|c|c|c|c|c|}
\hline & & & \multicolumn{4}{|c|}{ Detergent } & \multicolumn{4}{|c|}{ Urban Lake } \\
\hline & \multicolumn{2}{|c|}{ Control } & \multicolumn{2}{|c|}{ 1st month } & \multicolumn{2}{|c|}{ 5th month } & \multicolumn{2}{|c|}{ 1st month } & \multicolumn{2}{|c|}{ 5th month } \\
\hline & 1st month & 5th month & Average & $p$ & Average & $p$ & Average & $p$ & Average & $p$ \\
\hline Mucous & 0.6600 & 0.9200 & 14.8800 & $<0.05$ & 8.7200 & $<0.05$ & 24.7800 & $<0.05$ & 32.9400 & $<0.05$ \\
\hline Cells & (SD-1.3940) & (SD-1.5097) & (SD-6.0496) & & (SD-9.9715) & & (SD-7.0285) & & (SD-10.2189) & \\
\hline Chloride & 11.7000 & 11.4667 & 1.7333 & $<0.05$ & 2.1333 & $<0.05$ & 23.4839 & $<0.05$ & 25.5667 & $<0.05$ \\
\hline Cells & (SD-3.1200) & (SD-2.5962) & (SD-1.4840) & & (SD-2.1613) & & (SD-7.5448) & & (SD-7.0500) & \\
\hline Morphological Modifications & $\begin{array}{r}1.0000 \\
\text { (SD-1.1952) }\end{array}$ & $\begin{array}{r}1.2500 \\
(S D-1.5811)\end{array}$ & $\begin{array}{c}22.5000 \\
(S D-6.3920)\end{array}$ & $<0.05$ & $\begin{array}{c}16.7500 \\
(S D-5.1478)\end{array}$ & $<0.05$ & $\begin{array}{c}45.5000 \\
(S D-7.7644)\end{array}$ & $<0.05$ & $\begin{array}{r}27.8750 \\
(\text { SD-5.5918) }\end{array}$ & $<0.05$ \\
\hline
\end{tabular}

$\mathrm{SD}$ - standard deviation and $p$ - statistical results obtained in comparison with the control group.

only were there fewer cells but they were hypertrophied in contaminated exposure (Figure 6).

\section{Lysosome presence}

Epithelial cells in gill filaments and secondary lamellae of control groups contained lysosomes that were not found in exposed groups for both species (Figure 7).

\section{Discussion}

Several studies identified morphological alterations in fish gills after exposure to pollutants. Arellano et al. (2001) exposed Sparus aurata to 2,3,7,8-tetraclorodibenz- $p$-dioxin and found hyperplasia, hypertrophy, and lamellar fusion as well as chlorine cell hyperplasia. Cerqueira and Fernandes (2002) reported that copper $(\mathrm{Cu})$ in $P$. scrofa produced hypertrophy of the pavement and chlorine 

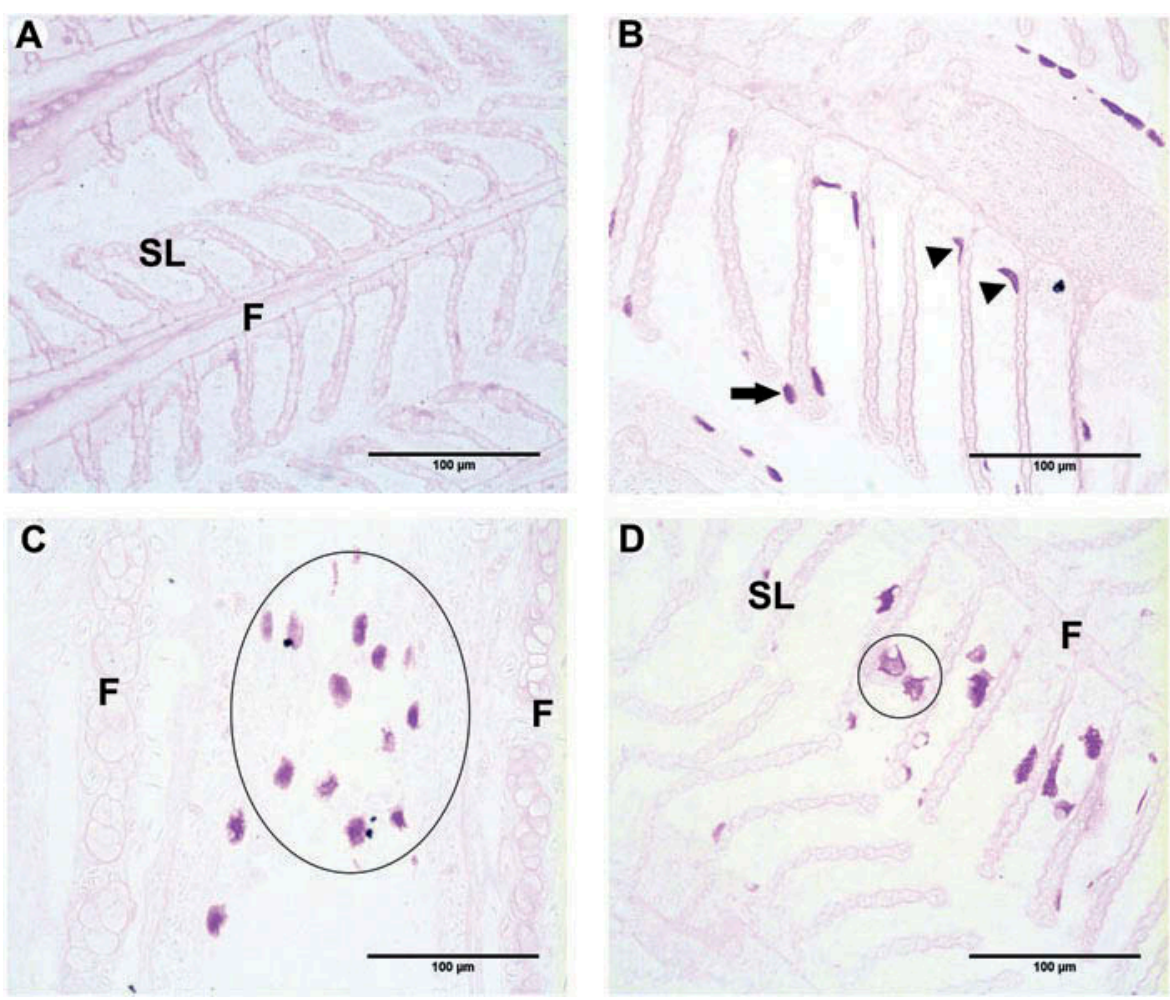

Figure 4. A - gill of Astyanax altiparanae, note that there is no positive reaction for mucous cells; $\mathrm{B}$ - gill of $A$. altiparanae, after explosion to pollutants, note the positive reaction for mucous cells in the secondary lamellae (arrow) and between them (arrowhead); C - lamellae fusion of two gill filaments (highlighted area), after explosion to pollutants, note the presence of many mucous cells; D - beginning of the lamellae fusion process, note that it starts with two mucous cells. The same pattern presented here was found for Prochilodus lineatus. F - gill filament; SL - secondary lamellae. Technique: PAS

Table 2. Average of mucous cells, chloride cells, and total of alterations found in the gills of the species Prochilodus lineatus. Note the increase in the number of mucous cells and morphological changes in detergent and the urban lake groups, compared to the control and the reduction in chloride cells in these same groups. No $P$. lineatus were found on lake on 5th month due the exposition to the pollutants.

\begin{tabular}{|c|c|c|c|c|c|c|c|c|c|c|}
\hline & & & \multicolumn{4}{|c|}{ Detergent } & \multicolumn{4}{|c|}{ Urban Lake } \\
\hline & \multicolumn{2}{|c|}{ Control } & \multicolumn{2}{|c|}{ 1st month } & \multicolumn{2}{|c|}{ 5th month } & \multicolumn{2}{|c|}{ 1st month } & \multicolumn{2}{|c|}{ 5th month } \\
\hline & 1st month & 5th month & Average & $p$ & Average & $p$ & Average & $p$ & Average & $p$ \\
\hline Mucous & 1.2600 & 1.1800 & 16.4400 & $<0.05$ & 18.5400 & $<0.05$ & 30.6800 & $<0.05$ & $N / R$ & \\
\hline Cells & (SD-2.0184) & (SD-1.3656) & (SD-12.4968) & & (SD-16.8186) & & (SD-9.4187) & & & \\
\hline Chloride & 9.2667 & 9.6667 & 1.6667 & $<0.01$ & 1.2667 & $<0.01$ & 3.5333 & $<0.01$ & $N / R$ & \\
\hline Cells & (SD-1.3629) & (SD-1.6678) & (SD-1.2910) & & (SD-1.3113) & & (SD-0.5074) & & & \\
\hline Morphological Modifications & $\begin{array}{c}1.0000 \\
(S D-1.0000)\end{array}$ & $\begin{array}{c}1.5000 \\
(S D-1.4142)\end{array}$ & $\begin{array}{r}28.1250 \\
\text { (SD-7.0394) }\end{array}$ & $<0.05$ & $\begin{array}{r}22.7500 \\
(S D-7.6298)\end{array}$ & $<0.05$ & $\begin{array}{r}36.7500 \\
\text { (SD-11.3232) }\end{array}$ & $<0.05$ & $N / R$ & \\
\hline
\end{tabular}

SD - standard deviation, $p$ - statistical results obtained in comparison with the control group and N/R - no results due the death of Prochilodus lineatus.

cells, epithelial detachment, lamellar fusion, and aneurysms. Ortiz-Ordonez et al. (2011) exposed Goodea atripinnis to herbicide concentrations and found hemorrhages and hypertrophy in the gills. Monteiro et al. (2008) in studies on Oreochromis niloticus with several $\mathrm{Cu}$ concentrations showed the development of aneurysms and cell hypertrophy. Mazon et al. (2002) demonstrated that exposure of P. scrofa to $\mathrm{Cu}$ led to pavement and chlorine cell hypertrophy and lamellar fusion. The present study noted that lamellar fusion and aneurysm were most frequent with both contaminant treatments, except for exposure of $P$. lineatus to urban lake water that led to higher indices of lamellar fusion and hypertrophy. The latter result was corroborated by Haaparanta et al. (1997) in 

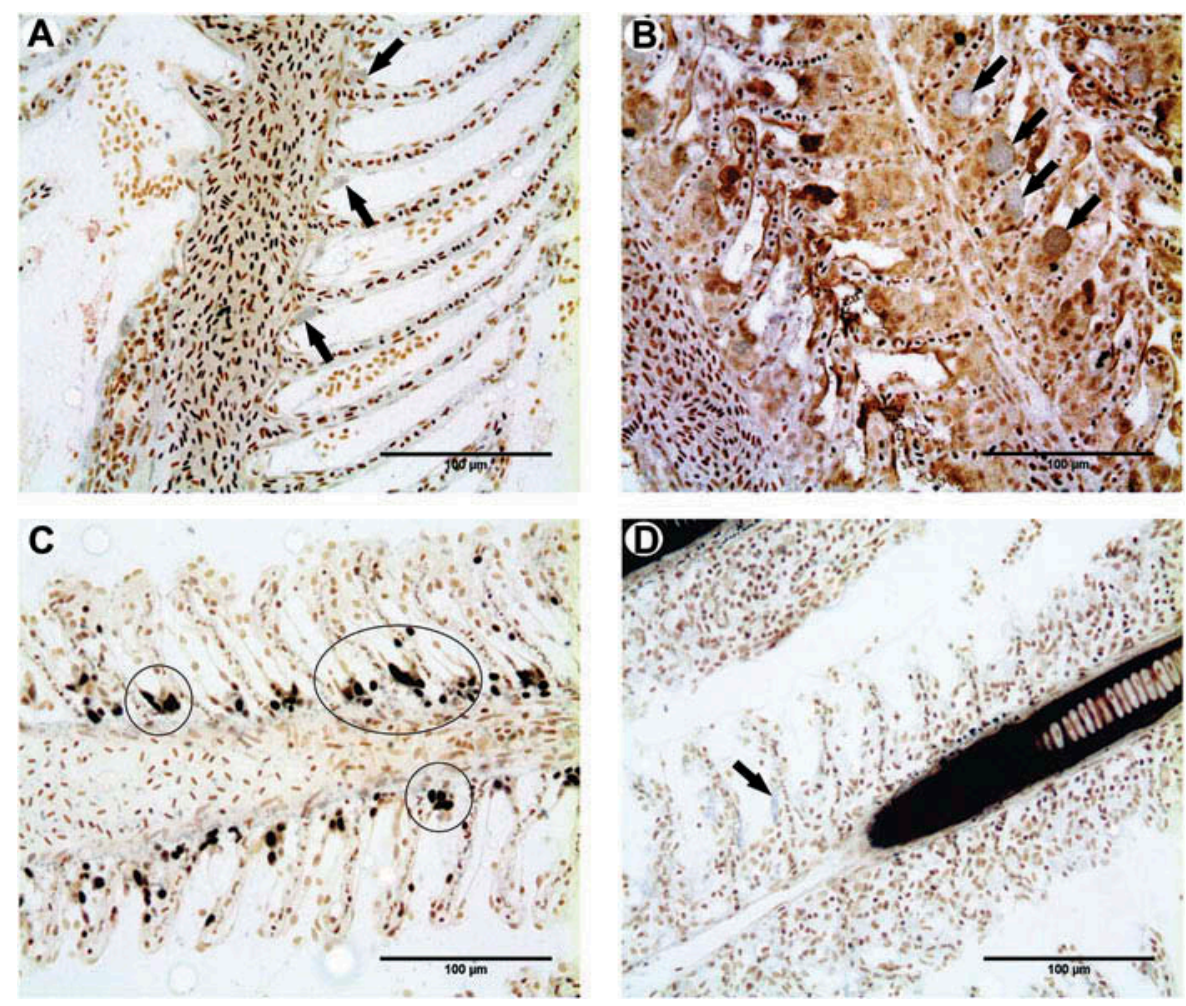

Figure 5. A - gill of Astyanax altiparanae, note the chloride cell distribution in the control group (arrow). The same pattern presented here was found for Prochilodus lineatus, in the control group; B - gill of $P$. lineatus exposed to pollutants, note the hypertrophy in the chloride cells (arrow); $C$ - gill of $A$. altiparanae exposed to the urban lake, note the proliferation of chloride cells (highlighted area); D - gill of A. altiparanae exposed to detergent, note the low number of chloride cells (arrow).

Technique: Von Kossa.
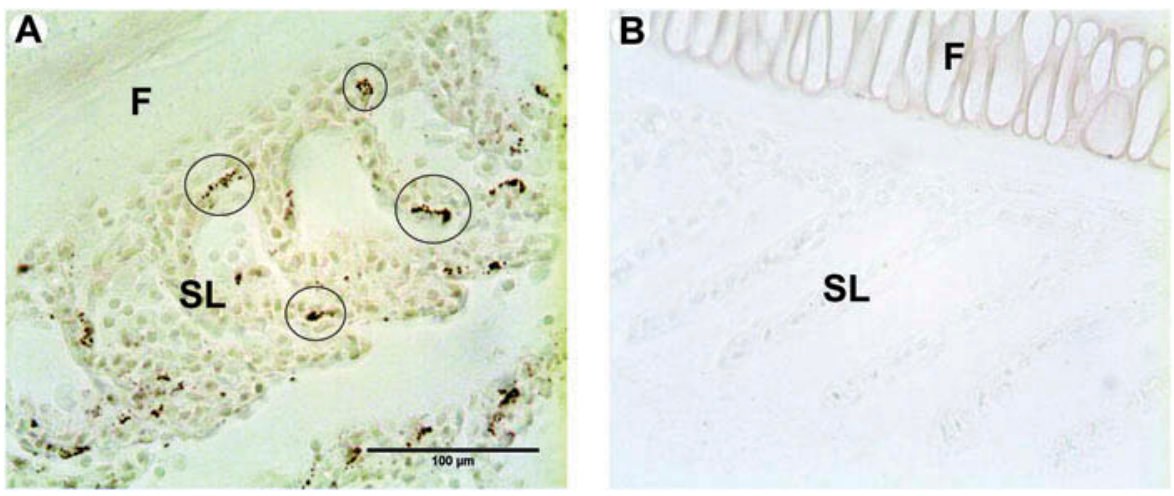

Figure 6. A - gill of Astyanax altiparanae, note the positive reaction for lysosomes (highlighted area). The same pattern presented here was found for Prochilodus lineatus, in the control group; B - gill of $A$. altiparanae after exposure to detergent, note the absence of lysosomes, the same pattern presented here was found for the urban lake and the exposed groups in $P$. lineatus.

F - gill filament; SL - secondary lamellae. Technique: Gomori.

fish in four lakes in Germany. Our data demonstrated that both waters tested contained a complex of contaminants and produced morphological remodeling such as lamellar fusion, epithelial, mucous and chlorine cell hypertrophy and hyperplasia, and in some cases aneurysms. 

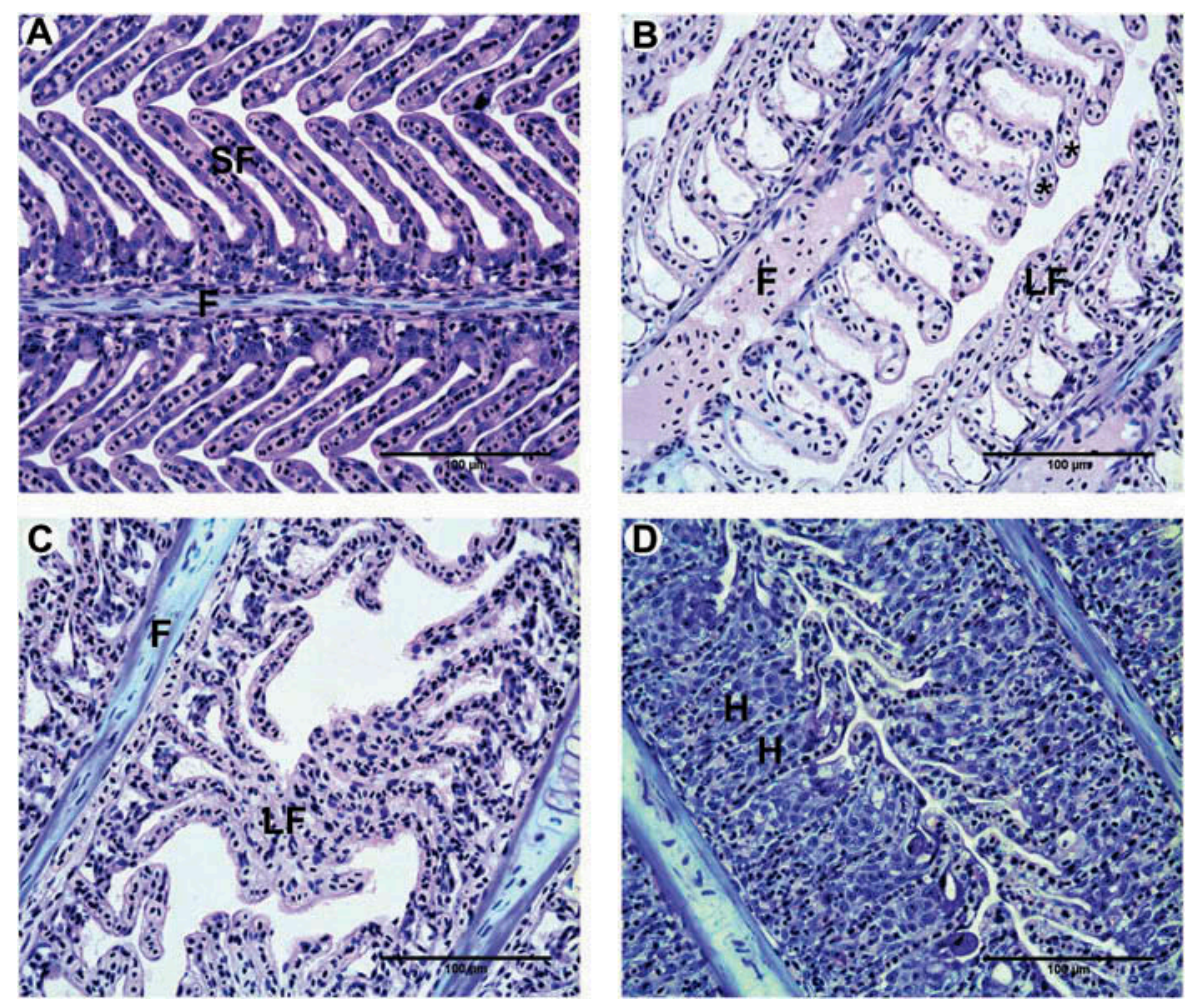

Figure 7. A - normal morphology of the gill in Prochilodus lineatus, showing the gill filament (F) and the secondary lamellae (SL); B gill of $P$. lineatus, showing aneurysms $\left(^{*}\right)$ in secondary lamellae and lamellae fusion (LF); $C$ - gill of $P$. lineatus, showing lamellae fusion between two different filaments (LF); D - gill of $P$. lineatus, showing hyperplasia of the gill filament epithelium (H).

Technique: $\mathrm{H}-\mathrm{E}$.

Amundsen et al. (2011) reported that heavy metals present in water enter the body of fish through the gills or digestive tract and metals such as $\mathrm{Cu}$, nickel $(\mathrm{Ni})$, and zinc $(\mathrm{Zn})$ are retained more in the gill tissue than in the liver in fish. Baraj et al. (2011) noted the presence of a mixture of metals resulted in a greater uptake of these elements in the gills. Domingos (2006) reported that some heavy metals such as iron, $\mathrm{Cu}, \mathrm{Zn}$, and cobalt are considered elements essential to the biological processes, but may be toxic at higher concentrations. There are several studies regarding the action of metals in fish, such as Pane et al. (2004) who carried out tests with aluminum, Camargo et al. (2009) who worked with this element, and Franchini et al. (1999) who tested lead, but reports of their effects combined with other elements are still rare in the literature. Todd et al. (2010) showed the negative impact of mixture of contaminant pollutants on marine fauna. The chemical analyses of the waters tested here indicated that the heavy metals present in the contaminated water in the highest concentration were iron and nickel in the lake and detergent. These elements alone at the concentrations found might be accounted for fish tissue alterations, but the effects observed may have been associated with those of other elements such as chlorine, fluor, nitrate, and the LAS surfactant.

There are a few studies on the effects of LAS in the gills and most are concentrated from the 1960s to the 1980s. Misra et al. (1985) exposed Cirrhinam rigala to LAS and showed lamellar fusion and chlorine cell proliferation. Abel and Skidmore (1975) found that trout-exposed detergent presented chlorine cell proliferation and cell hypertrophy. Roy (1988) also reported variation in the quantity of mucous cells in Rita rifa after exposure to the same pollutant. Our results also showed mucous cell proliferation, but a high incidence of lamella was identified that was not demonstrated in previous studies. This was due to the presence of $\mathrm{Ni}$ that enhances the damage. Brown et al. (1968) found that when trout were exposed to a mixture of metals and detergents the 
effects were enhanced as compared to the same effect of the separate pollutants.

Pereira et al. (2012) demonstrated that lamella epithelium hypertrophy and chloride and mucous cell proliferation are examples of defense mechanisms against toxic agents that prevent the chemical from entering the organism but these mechanisms alter water-blood balance and hinder the effectiveness of gas exchange. Data showed that lamellar fusions are formed to mechanically isolate the blood from the water, increasing their distance. However, the results of the present study indicated that in some cases these fusions also played a chemical protection role as evidenced by formation of these modifications by mucous cell diffusion and proliferation.

Reis et al. (2009) noted that fish gill surface is covered by mucus which serves to protect fish against fluctuations in the physical, chemical, and biological parameters of the aquatic environment. This form of protection is assessed by the number of glycoprotein producing cells (mucins) that make up this mucus and by analyzing the chemical characteristics of their components (Reis et al., 2009). Mucous cell proliferation and hypersecretion in the gills in stress situations are regarded as a defense mechanism in function in situations of gill damage. Mucous cell proliferation found in the present study indicated that both contaminant complexes generated hypersecretion in the gills of the species tested. This event was generated for chemical defense but together with the structural modifications in the filament and lamella, resulted in not only isolating the contaminant agent but also in hindering oxygen passage to the blood.

It is known that chlorine cells are the active sites of ion transport regulation in marine and freshwater fish (Perry, 1997). This regulation, especially in marine fish, represents a substantial part of the energetic budget due to adenosine triphosphate (ATP) hydrolysis by several ion-ATPase transporters. These include high-affinity $\mathrm{Na}^{+} / \mathrm{K}^{+}$-ATPase $\mathrm{Ca}^{2+}$-ATPase and perhaps the poorly defined $\mathrm{Cl}^{-} / \mathrm{HCO}_{3}{ }^{-}-\mathrm{ATPase}$. In unfavorable ionic conditions or in contact with toxic agents, chlorine cells proliferate in the gills and on the lamella surface of the gills (Perry, 1997). Perry and Walsh (1989) found that chlorine cells have a higher metabolic rate than other cells in the gills and thus the metabolic rate of the rest of the gills directly affects the chlorine cell population and stimulates proliferation. Alberto et al. (2005) demonstrated that fish of the A. fasciatus species collected in rivers with sewage disposal showed an increase in the chlorine cell density in order to optimize Fe regulation, but these variations diminished oxygen absorption capacity because they increased the distance between blood and water. Our results demonstrated and in the case of detergent solution, the damage caused are regardless of the species, the number of chlorine cells fell. In the case of exposure to lake water proliferation of chlorine cells in A. altiparanae occurred while in $P$. lineatus decreased on it's number was noted. Data showed that the contaminants directly affected the ionic-regulation-stimulated cell proliferation and hindered oxygen absorption.

Malicdan and Nishino (2012) reported that lysosomes are responsible for digestion and metabolism, especially the intra-cell components, or act in cell recycling. However, these constituents also act in the metabolism of external components absorbed by the cell. Gernhöfer et al. (2001) in rivers in Germany found lamellar fusion, mucous and chlorine cell, and lysosome proliferation in gills. Bearing in mind the action of digestion of exogenous materials absorbed by the cell, lysosome proliferation was expected in the present experiment. However, the urban water tested inhibited formation of the structures.

\section{Conclusion}

This study showed that biodegradable detergents are pollutants that produce several morphological alterations in fish gills and when combined with other substances, as occurring in nature, their effects are enhanced further adding to the damage to the fauna in rivers and urban lakes. This study demonstrated that the morphological approach is a way to identify pollutant effects and may be used as a biomonitor for physiological responses to environment in fish.

\section{Acknowledgments}

The authors are thankful to FAPESP process number: 2009/ 17118-9 for financial support and to ICMBio/CEPTA, Institute Chico Mendes for providing the specimens used in this experiment. 


\section{ORCID}

Fellipe Augusto Tocchini De Figueiredo (D) http://orcid.org/ 0000-0001-9924-9751

\section{References}

Abel, P. D. 1996. Water pollution biology. Second. London: Taylor \& Francis.

Abel, P. D. and Skidmore, J. F. 1975. Toxic effects of an anionic detergent on the gills of rainbow trout. Water Res. 9: 759-765.

Adeogun, A. O., Chukwuka, A. V., Okoli, C. P., and Arukwe, A. 2016. Concentration of polychlorinated buphenyl (PCB) congeners in the muscle of Clarias gariepinus and sediment from inland rivers of southwestern Nigeria and estimated potential human health consequences. J. Toxicol. Environ. Health Part A. 79: 969-973.

Aich, A., Goswami, A. R., Roy, U. S., and Mukhopadhyay, S. K. 2015. Ecotoxicological assessment of tannery effluent using guppy fish (Poecilia reticulata) as an experimental model: a biomarker study. J. Toxicol. Environ. Health Part A. 78: 278-286.

Alberto, A., Camargo, A. F., Verani, J. R., Costa, O. F., and Fernandes, M. N. 2005. Health variables and gill morphology in the tropical fish Astyanax fasciatus from a sewagecontaminated river. Ecotoxicol. Environ. Saf. 61: 247-255.

Amundsen, P. A., Kashulin, N. A., Terentjev, P., Gjelland, K. O., Koroleva, I. M., Dauvalter, V. A., Sandimirov, S., Kashulin, A., and Knudsen, R. 2011. Heavy metal contents in whitefish (Coregonus lavaretus) along a pollution gradient in a subarctic watercourse. Environ. Monit. Assess. 182: 301-316.

Arellano, J. M., Ortiz, J. B., Canales, M. L. G., and Sarasquete, C. 2001. Histopathological alterations and induction of cytochrome P-450 1A in the liver and gills of the gilthead seabream (Sparus aurata) exposed to 2,3,7,8-tetrachlorodibenzo-p-dioxin. Histochem. J. 33: 663-674.

Baraj, B., Niencheski, F., Fillmann, G., and De Martinez Gaspar Martins, C. 2011. Assessing the effects of $\mathrm{Cu}, \mathrm{Cd}$, and exposure period on metallothionein production in gills of the Brazilian brown mussel Perna perna by using factorial design. Environ. Monit. Assess. 179: 155-162.

Becak, W. and Paulete, J. 1976. Técnicas De Citologia E Histologia. Rio de Janeiro: Nobel.

Brown, V. M., Mitrovic, V. V., and Stark, G. T. C. 1968. Effects of chronic exposure to zinc on toxicity of a mixture of detergent and zinc. Water Res. 2: 255-263.

Camargo, M. M., Fernandes, M. N., and Martinez, C. B. 2009. How aluminium exposure promotes osmoregulatory disturbances in the neotropical freshwater fish. Prochilus Lineatus. Aquat Toxicol. 94: 40-46.

Cerqueira, C. C. and Fernandes, M. N. 2002. Gill tissue recovery after copper exposure and blood parameter responses in the tropical fish. Prochilodus Scrofa. Ecotoxicol Environ. Saf. 52: 83-91.
De Campos, E. O., Jr, Oliveira, R. G. S., Pereira, B. B., Souto, H. N., Campos, C. F., Nepomuceno, J. C., and Morelli, S. 2016. Assessment of gtenotoxic, mutagenic and recombinanogenic potential of water resources in the Paranaiba River basin, Brazil: A case study. J. Toxicol. Environ. Health Part A. 79: 1190-1200.

Domingos, F. X. V. 2006. Biomarcadores de contaminação ambiental em peixes e ostras de tres estuários brasileiros e cinética de derivados soluveis do petroleo em peixes Postgraduate Program in Cellular and Molecular Biology, Sector of Biological Sciences, Federal University of Paraná.

Fernandes, M. N. and Perna-Martins, S. A. 2001. Epithelial gill cells in the armored catfish, Hypostomus cf. plecostomus (Loricariidae). Rev. Brasil Biol. 61: 69-78.

Franchini, A., Rebecchi, B., and Bolognani Fantin, A. M. 1999. Gill endocrine cells in the goldfish Carassius carassius var. auratus and their impairment following experimental lead intoxication. Histochem. J. 31: 559-564.

Gernhöfer, M., Pawert, M., Schramm, M., Müller, E., and Triebskorn, R. 2001. Ultrastructural biomarkers as tools to characterize the health status of fish in contaminated streams. J. Aquat. Ecosyst. Stress Rec. 8: 241-260.

Gomori, G. 1950. An improved histochemical technic for acid phosphatase. Stain. Technol. 25: 81-85.

Haaparanta, A., Valtonen, E. T., and Hoffmann, R. W. 1997. Gill anomalies of perch and roach from four lakes differing in water quality. J. Fish Biol. 50: 575-591.

Hawkins, A. D., Thornton, C., Kennedy, A. J., Bu., K., Cizdzeil, J., Jones, B. W., Steevens, J. A., and Willett, K. K. 2015. Gill histopathologies following exposure to anosilver os silver nitrate. J. Toxicol. Environ. Health Part A. 78: 3021-3315.

Jobling, M. 1994. Environmental Biology of Fishes. Springer: Netherlands.

Kaur, R. and Dua, A. 2015. Scales of freshwater fish Labeo rohita as bioindicators of water pollution in Tung Dhab Drain, Amritsar, Punjab, India. J. Toxicol. Environ. Health Part A. 78: 388-396.

Leonardo, J. M. L. O., Vargas, L., Ribeiro, R. P., Moreira, H. L. M., Natali, M. R. M., Volski, T., and Cavichiolo, F. 2008. Histologia das brânquias de larvas da tilápia do Nilo, Oreochromisniloticus (L.), de origem tailandesa, submetidas a diferentes níveis de vitamina C. Acta Sci. Animal Sci. 23: 863-870.

Malicdan, M. C. and Nishino, I. 2012. Autophagy in lysosomal myopathies. Brain Pathol. 22: 82-88.

Mazon, A. F., Cerqueira, C. C. C., and Fernandes, M. N. 2002. Gill cellular changes induced by copper exposure in the South American tropical freshwater fish. Prochilodus Scrofa. Environ. Res. 88: 52-63.

Misra, V., Lal, H., Chawla, G., and Viswanathan, P. N. 1985. Pathomorphological changes in gills of fish fingerlings (Cirrhina mrigala) by linear alkyl benzene sulfonate. Ecotoxicol. Environ. Saf. 10: 302-308.

Monteiro, S. M., Rocha, E., Fontaínhas-Fernandes, A., and Sousa, M. 2008. Quantitative histopathology of 
Oreochromis niloticus gills after copper exposure. J. Fish Biol. 73: 1376-1392.

Ogeleka, D. F., Ezemonye, L. I., and Okieimen, F. E. 2011. The toxicity of a synthetic industrial detergent and a corrosion inhibitor to brackish water fish (Tilapia guineensis). Turk J. Biol. 35: 161-166.

Ortiz-Ordonez, E., Uria-Galicia, E., Ruiz-Picos, R. A., Duran, A. G., Trejo, Y. H., Sedeno-Diaz, J. E., and Lopez-Lopez, E. 2011. Effect of yerbimat herbicide on lipid peroxidation, catalase activity, and histological damage in gills and liver of the freshwater fish. Goodea Atripinnis. Arch. Environ. Contam. Toxicol. 61: 443-452.

Pane, E. F., Haque, A., and Wood, C. M. 2004. Mechanistic analysis of acute, Ni-induced respiratory toxicity in the rainbow trout (Oncorhynchus mykiss): an exclusively branchial phenomenon. Aquat.Toxicol. 69: 11-24.

Pereira, B. F., Alves, R. M. S., Pitol, D. L., Senhorini, J. A., Rocha, R. C. G. A., and Caetano, F. H. 2012. Morphological gill analysis of fish species Prochilodus Lineatus after exposure to pollutants. J. Environ. Anal. Toxicol.. 2(3).

Pereira, B. F. and Caetano, F. H. 2009. Histochemical technique for the detection of chloride cells in fish. Micron. 40: 783-786.

Perry, S. F. 1997. The chloride cell: structure and function in the gills of freshwater fishes. Annu. Rev. Physiol. 59: 325-347.

Perry, S. F. and Walsh, P. J. 1989. Metabolism of isolated fish gill cells: contribution of epithelial chloride cells. J. Exp. Biol. 144: 507-520.

Reis, A. B., De MG Sant'Ana, D., Azevedo, J. F., Merlini, L. S., and Araújo, E. J. A. 2009. Alterações do epitélio branquial e das lamelas de tilápias (Oreochromis niloticus) causadas por mudanças do ambiente aquático em tanques de cultivo intensivo. Pesquisa Vet. Brasileira. 29: 303-311.

Roy, D. 1988. Toxicity of an anionic detergent, dodecylbenzene sodium sulfonate, to a freshwater fish, Rita rita: determination of LC50 values by different methods. Ecotoxicol. Environ. Saf. 15: 186-194.

Silva, L. D., Nascimento, V., CSantos, S., Morais, J. O. R., and Sabóia-Morais, S. M. T. 2003. Análise morfométrica das células do cloro de Poecilia vivipara expostas a frações da folha e casca do caule de Caryocar brasiliensis. Acta Sci Biol Sci. Maringá. 25: 195-201.

Strbac, S., Kasanin-Grubin, M., Jovancicevic, B., and Simonovic, P. 2015. Bioaccumulation of heavy metals and microelements in silver bream (Brama brama L.), northern pike (Esox lucius L.), sterlet (Acipenser ruthenus L.), and common carp (Cyprinus carpio L.) from Tisza River, Serbia. J. Toxicol. Environ. Health Part A. 78: 663-665.

Takashima, F. and Hibiya, T. 1995. An Atlas of Fish Histology: Normal and Pathological Features. New York: G. Fischer.

Todd, P. A., Ong, X., and Chou, L. M. 2010. Impacts of pollution on marine life in Southeast Asia. Biodivers. Conserv. 19: 1063-1082.

Vaz, S., Silva, S., Dias, A. H., Dutra, E. S., Pavanin, A. L., Morelli, S., and Pereira, B. B. 2016. The impact of water pollution on fish species in southeast region of Goias, Brazil. J. Toxicol. Environ. Health Part A. 79: 8-16.

Wolff, S., Brown, G., Chen, J., Meals, K., Thornton, C., Brewer, S., Cizdziel, J. V., and Willett, K. L. 2016. Mercury concentrations in fish from three major lakes in north Mississippi: spatial and temporal differences and human health risk assessment. J. Toxicol. Environ. Health Part A. 79: 894-904. 